\title{
MEASUREMENTS OF SEASONAL VARIATIONS OF RADIOACTIVITY DISTRIBUTIONS IN RIVERINE SOIL SEDIMENT OF ADO-ODO OTA, SOUTH-WEST NIGERIA: PROBABILISTIC APPROACH USING MONTE CARLO
}

Omeje Maxwell ${ }^{1}$, O Adewoyin Olusegun ${ }^{1}$, Emmanuel S. Joel ${ }^{1}$, Ijeh Ikechukwu B. ${ }^{2}$, A Timothy-Terhile Mary ${ }^{2}$, E Okoro Emeka ${ }^{3}$, Omeje Anne Uchechukwu ${ }^{4}$, Bosede Ngozi Adeleye ${ }^{5}$,

OROSUN Muyiwa Michael ${ }^{\text {ID }}{ }^{6}$, Oha A. Ifeanyi ${ }^{7}$, Iyanuoluwa E. Ogunrinola ${ }^{1}$, F Ahuekwe Eze $^{8}$ and M. A. Saeed ${ }^{9}$

${ }^{1}$ Department of Physics, College of Science and Technology, Covenant University, P.M.B 1023, Ota, Ogun

State, Nigeria

${ }^{2}$ Department of Physics, Michael Okpara University of Agriculture, Umudike, Umuahia, Abia State, Nigeria

${ }^{3}$ Department of Petroleum Engineering, College of Engineering, Covenant University, P.M.B 1023, Ota,

Ogun State, Nigeria

${ }^{4}$ Department of Public and Community Health Care, College of Medicine, Idiaraba, University of Lagos,

Nigeria

${ }^{5}$ Department of Economics and Development Studies, Covenant University, P.M.B. 1023, Ota, Ogun State,

Nigeria

${ }^{6}$ Department of Physics, University of Ilorin, Ilorin, Kwara State, Nigeria

${ }^{7}$ Department of Geology, University of Nigeria, Nsukka, Enugu State, Nigeria

${ }^{8}$ Department of Biological Sciences, College of Science and Technology, Covenant University, P.M.B 1023, Ota, Ogun State, Nigeria;

${ }^{9}$ Department of Physics, Division of Science and Technology, University of Education, Lahore-Pakistan

*Corresponding author: maxwell.omeje@covenantuniversity.edu.ng

Received 23 October 2020; revised 14 January 2021; editorial decision 1 February 2021;; accepted 1 February 2021

The radioactivity levels were measured using a hand-held gamma-ray survey meter and $\mathrm{NaI}$ (TI) based gamma spectroscopy to evaluate the seasonal variation of radioactivity levels in the riverine area of Ado-Odo Ota. The measured iso-dose map reported higher gamma dose rate of $79 \mathrm{nGy} / \mathrm{h}$, approximately $34 \%$ higher than the world average of $59 \mathrm{nGy} / \mathrm{h}$. The values for U-238, Th232 and K-40 activity levels ranged between 29.9 and 21.6; 103.2 and 31.2; 802.2 and 233.5 with mean values of 26.1, 55.6 and 499.3 Bq/kg, respectively. According to the mean, 5th and 95th percentiles of the probabilities using the Monte Carlo simulation, the Radium equivalent activities and the absorbed dose rates are within their respective recommended limits of $370 \mathrm{~Bq} / \mathrm{kg}$ and $84 \mathrm{nGy} / \mathrm{h}$. This study could be used to monitor dose rates and radiological risks for the areas covering the small area (Ado-Odo Ota) to the larger area (West African Region) as baseline data.

\section{INTRODUCTION}

The radionuclides in the marine environment could be either natural particles of the earth's crust manifesting in all terrestrial ecosystem or anthropogenic sources $^{(1,2)}$. Another threat to the marine environment is the anthropogenic sources such as industrial activities, agricultural and mining activities ${ }^{(3)}$. West African coastal region lacks information about the nuclear industry operations, mining, industrialization, agricultural production, offshore gas and oil exploration could attribute to the increase in radioactivity level of an environment ${ }^{(4,5)}$. Consequently, the West African anthropogenic activities in the coastal environment such as production, mining, industrialization, agricultural production, offshore gas and oil exploration could contribute to the radioactivity level of an environment ${ }^{(4,6)}$. Human exposure to radiation from the soil may occur through exposure to background radiation due to the existence of the primordial radionuclides in the soil or through inhalation of dust from the soil sediments that usually contains these radionuclides ${ }^{(7)}$. The exposure to radiation from radon and its decay progeny that sometimes emanate from the soil sediments internally affects the respiratory tracks ${ }^{(5)}$. Soil-to-plant-to-human and/or soil-toplant-to-animal-to-human transfer of these radioelements are additional routes of human exposure to ionizing radiation via food chain ${ }^{(5)}$.

Radionuclides could appear as toxic elements and undergo bioaccumulation and bioconcentration, 
resulting in adverse impact on human and ecosystem health ${ }^{(8)}$. The alteration in the activity concentrations of radionuclides in the natural ecosystem has resulted in an understanding of health implications over the past years. These radionuclides penetrate the tissues of the marine species through different mechanisms. Accordingly, these radionuclides penetrate the food chain through the ingestion of sea or marine food ${ }^{(9)}$.

The evaluation of some trace metal pollutants in River Atueara located in Southwestern Nigeria and Spatio-temporal, human health risks assessment suggested that $\sim 1$ in 10 adults and 1 in 20 children may suffer over their lifetime as a result of consumption and exposure to water from River Atueara ${ }^{(10)}$. So many activities truncate the radioactivity and chemical processes of the biological community of the environmental ecosystem, which includes community activities, industrial operations, land-use change and climate change. Conversely, to improve and sustain river health system, an accurate assessment of the radioactivity of sediment samples is highly needed ${ }^{(11)}$. Researchers have mapped out a holistic approach to quantify and evaluate river water quality parameters and their risk exposure to the human and environmental ecosystem ${ }^{(11)}$. An earlier study was conducted by Omeje et al. ${ }^{(12)}$ during rainy season on the background radiation dose rates along Iju river soil sediments and its radiological risks were revealed with some significant hotsports and the distribution of gamma dose rates. At the same time, there is an urgent need to ascertain the individual radionuclides spatial distribution in dry season, which will help in deriving vital conclusion especially on the seasonal effects, trend of distribution and the probabilistic risk analysis of the soil sediment of Iju river. Hence, the aim of this study is to ascertain the seasonal variation of the background gamma dose rates, activity concentrations of U-238, Th-232 and K-40 within the riverine sediments and to perform the probabilistic risk analysis of the measured Radium equivalent and gamma dose rate using the Monte Carlo simulation (MCS). Thus, probabilistic approach using the MCS has been appropriately employed in this work to assess more realistic risk related to the primordial radionuclides (U-238, Th-232 and K-40) present in the samples.

\section{STUDY AREA}

The study area is located in Ogun State, South-West, Nigeria, which lies within the latitude $6.9^{\circ} \mathrm{N}$ and longitude $3.6^{\circ} \mathrm{E}$. Ogun State is an inland state and is bounded to the North by Oyo and Osun States, to the South by Lagos State, to the East by Ondo State and to the West by the Benin Republic. Ogun State has a tropical climate with an average temperature of $27.1^{\circ} \mathrm{C}$ and rainfall of $1238 \mathrm{~mm}$. Ogun State with other south-western Nigerian states including Oyo and Lagos States, lies in the eastern Dahomey Basin. Its geology is composed of sedimentary and basement complex rocks that are late cretaceous to early tertiary ${ }^{(12,13)}$. Stratigraphically, the sedimentary rock of Ogun State consists of the Abeokuta group, Imo group, Ewekoro, Oshosun, Ilaro and Benin formations ${ }^{(14)}$. The cretaceous Abeokuta group constitutes the Ise, Afowo and Araromi formations and lies on top of the basement complex. The Abeokuta group is overlain by the Ewekoro, Oshosun and Ilaro formations that are all overlain by the Benin formation made up of coastal plain sands ${ }^{(11)}$ as shown in Figure 1.

\section{The coastline sediments of Iju river}

The coastal nature of the Iju river sediments shows some parts where communities have access to the river for fishing and fetching water for domestic purposes $^{(12)}$. They are almost parallel to the coastline sediments of other rivers such as River Atueara that is located $\sim 5$ kilometres away from Iju town. The deposits of River Iju comprise of mudflats, salt marsh and inner sandy flats. Within the river subenvironments, it cuts across the creeks and bordering areas. Surface features such as vegetation, an association of different sediments, sedimentary structures and textures, characterize the sub-environments along the coastal river. The sediments contain high contents of iron, phosphate, nitrate and sulphates ${ }^{(15)}$. The tidal water along the river decreases its capacity towards the intertidal zone, which increases the sediments deposits and as well reduces the size of the grains. These processes seem to be modified by the secondary agents caused by waves for rearrangements of the sediments in the study area.

\section{MEASUREMENTS OF GAMMA RADIATION DOSE LEVEL}

Portable hand-held radiation detector (Super-SPEC RS-125) from Canadian Geophysical Inc. was used to measure the background gamma dose level in the study area at the middle of dry season to compare the variations with Maxwell et al. ${ }^{(12)}$ that was conducted during rainy season. This instrument is most suitable for detecting naturally occurring radionuclides and dose exposure. The equipment has a high degree of accuracy with probable measurement errors of $\sim \pm 5 \%$ $(12,16)$. The portable equipment has an incorporated design and direct assay read-out values, storage data point with weather protection, easy to use and highly sensitive. The number of count display of RS-125 Super-SPEC in the front side of the panel in cps at $1 / \mathrm{s}$ update rate. The variable rate counts of the SCAN mode of RS-125 Super SPEC usually stores data in 


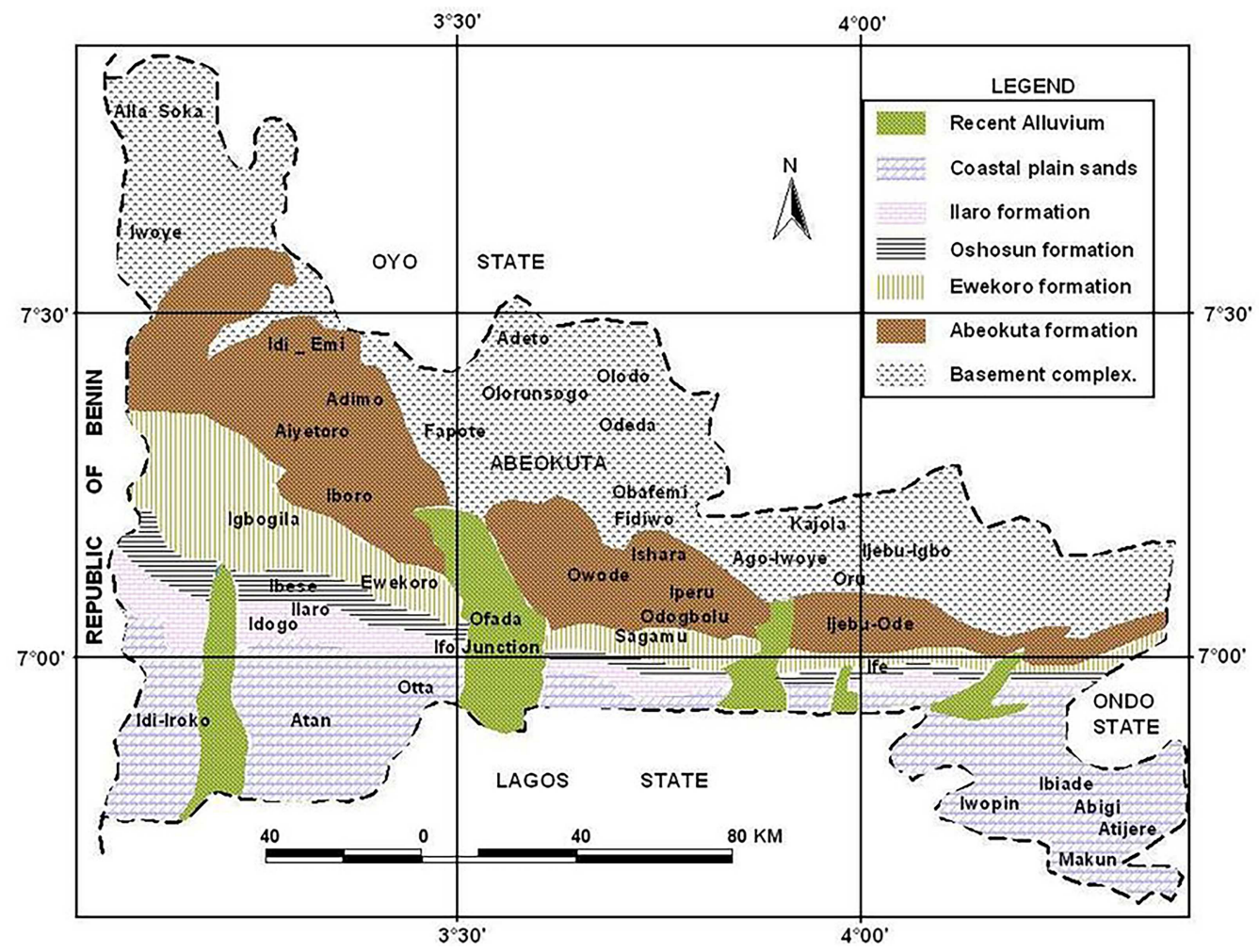

Figure 1: Geological map of Ogun State with red arrow pointing the study location Source: Authors' computations from Nigerian geological survey agency.

the memory of the device through bluetooth connection to external storage of the hand-held device. The location of the data is gotten through the connection of external Global Positioning System (GPS) to the data stream via Bluetooth connection to the device. In the study area, the measurements were taken at intervals of $50 \mathrm{~m}$ following the regions that constitute high soil sediment deposits to the areas with less sediment deposits, gully and weathered surface areas. Few zones of lower sediments from the riverbanks were taken as control. At each station, four different measurements were taken and the average obtained was used to represent the actual data point for that site. At each point of measurement, the sediment sample was collected for laboratory gamma ray spectroscopy counting. The natural background gamma dose measurements is provided by the assay mode of RS-125 Super SPEC and dose rate data are directly acquired in $\mathrm{nGy} / \mathrm{h}$. The RS-125 Super SPEC comes with utility software that is used to download the statistics record that is stored in memory and further connected to the computer through Bluetooth or USB. The measured data are stored in excel sheet with proper coordinates was processed, georeferenced and interpolated using ArcGIS (version 10.8) spatial analysis. Figure 2 presents the result of the ArcGIS spatial distribution of dose rate measured along the River Iju.

\section{Method of GIS analysis of background dose rates data samples measured along riverine sediments}

The spatial distribution of gamma dose rates in sediments of Iju River was first carried out using an interpolated scheme with the inverse distance weighting interpolation function being applied on all the sediment samples measured. The interpolated functions were used as input to the ArcGIS 10.8 $8^{(10,12,17)}$. This current gamma measurements were carried out to compare with the previous study conducted during the rainy season along Iju River soil sediments.

\section{Sample collection and preparation}

In the study area, a total number of 13 sediment samples along Iju River were scooped from a depth of $10 \mathrm{~cm}$ to collect $1000 \mathrm{~g}$ of samples at each marked site with a distance of $50 \mathrm{~m}$ from each point at the 


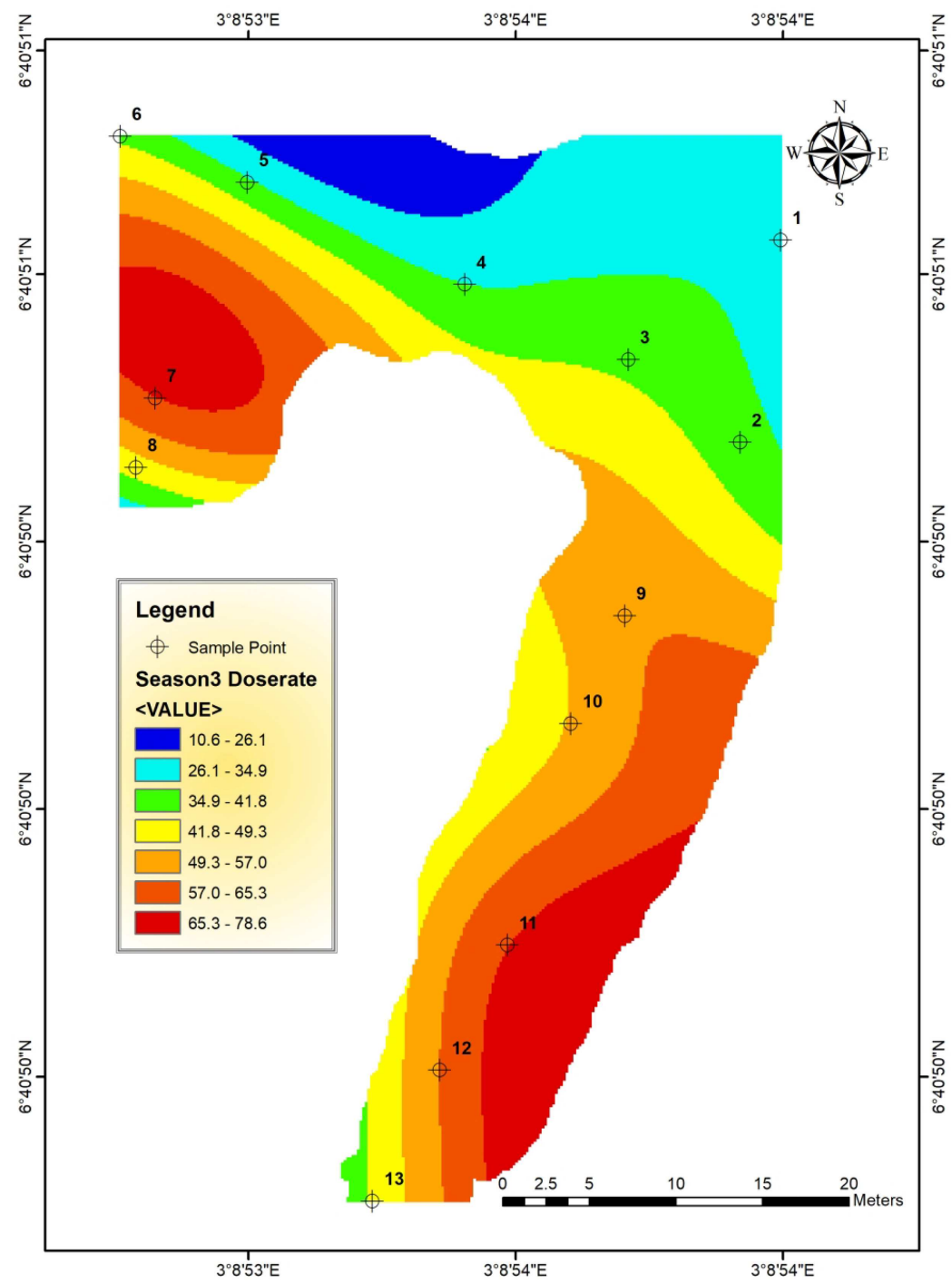

Figure 2: Spatial distribution of dose rates from the sediment samples of Iju river. Source: Authors' computations.

middle of dry season to estimate the variation in the activity levels with the earlier study monitored by Maxwell et al. ${ }^{(12)}$. These points were chosen based on the areas that communities access the river water for consumption and other domestic purposes. Each sediment sample was air-dried under the ambient temperature of $29^{\circ} \mathrm{C}$ for 1 week to lessen the mass contribution of water and to inhibit any chemical reaction $^{(18)}$. The soil sediment samples were crushed, powdered to a maximum grain size of 1 millimetre, dried in an oven at $\sim 105^{\circ} \mathrm{C}$ until the samples maintained a constant weight of $\sim 500 \mathrm{~g}$. Each sample was sealed in high-density polyethene plastic bottles, labelled accordingly and sent to Activation analysis
Laboratory in Canada for gamma counting. All the samples were sealed in a radon impermeable plastic container for 4 weeks to bring Rn-222 and its shortlived radionuclide daughters products into equilibrium with $\mathrm{Ra}-226^{(12,18,19)}$.

\section{Method for gamma spectroscopy analysis of sediment samples}

The concentrations of U-238, Th-232 and K-40 measured in $\mathrm{Bq} / \mathrm{kg}$ dry weight of the samples from Iju River were analysed using gamma-ray spectrometry method. A NaI (Tl) detector $3^{\prime} \times 3^{\prime}$ was used with 
proper lead shielding to reduce the background contribution by a factor of $\sim 95 \%$. The determination of various radionuclides concentrations of interests in $\mathrm{Bqkg}^{-1}$ was measured using count spectra (19). The photo peaks (region of interest) of the gammaray corresponds to $1.46 \mathrm{MeV}$ for K-40, $1.76 \mathrm{MeV}$ for $\mathrm{Bi}-214$ and $2.614 \mathrm{MeV}$ for TI-208 considered to be the activities of K-40, U-238 and Th-232, respectively, in the Iju River soil sediment samples. The $\mathrm{NaI}$ (Tl) detector used has detection limit of 8.50, 2.21 and $2.11 \mathrm{~Bq} / \mathrm{kg}$ for K-40, U-238 and Th-232, respectively ${ }^{(12,18)}$. The counting time of $21000 \mathrm{~s}$ for each sample was adopted ${ }^{(18,20)}$. The activity concentrations were calculated using Equation $(1)^{(12,21)}$.

$$
C_{\mathrm{s}}=C_{\text {ref }} \frac{\frac{P_{\mathrm{s}}}{D_{\mathrm{s}}}-\frac{P_{\mathrm{b}}}{D_{\mathrm{b}}}}{\left(\frac{P_{\text {ref }}}{D_{\text {ref }}}-\frac{P_{\mathrm{b}}}{D_{\mathrm{b}}}\right) M_{\mathrm{s}}},
$$

where $C_{\mathrm{s}}$ and $C_{\text {ref }}$ are the activity concentrations in $\mathrm{Bq} / \mathrm{kg}$ of the measured sediment samples and standard reference materials, respectively. $P_{\mathrm{s}}, P_{\text {ref }}$ and $P_{\mathrm{b}}$ are the photopeak areas of the sediment samples, standard reference materials and the background photopeak gamma limes, respectively, which is dimensionless. Also, $D_{s}, D_{\text {ref }}$ and $D_{b}$ are the counting duration/time in seconds for the sediment samples, standard reference materials and background, respectively.

\section{Multivariate analysis}

Initial statistical two-way analysis of variance (ANOVA) was estimated on Excel to compare the variation in the sites with the observed days. The regression analysis was performed in R-Studio 3.0.2 version $^{(12)}$. The categorical variables were converted into dummy variables in Excel such that the numbers ' 0 ' and ' 1 ' can be used to identify each value of the variables accordingly. Thereafter, the dummy variables were inputted into R-Studio 3.0.2 version alongside the dependent variables. The results of the analysis were thereafter generated.

\section{RESULTS AND DISCUSSIONS}

\section{Spatial distribution of background dose rate from the sediment samples in the study area}

The background gamma dose measurements in the study area is presented in Iso-dose map (Figure 2). The gamma dose rates comprise different variations in dose distributions within the study area showing the highest background dose areas as the hotspots. The highest background gamma dose (hotspot) was identified in site 7 and 11 with background dose rates ranges from 56 to $79 \mathrm{nGy} / \mathrm{h}$. Comparing this range of gamma dose rates with a study conducted during the rainy season by ${ }^{(12)}$, with values ranging from 21.6 to $58.9 \mathrm{nGy} / \mathrm{h}$, this current study is slightly higher, which may be the effect of change in temperature that increases soil sedimentation. The entire study area recorded the background dose ranges between 11 and $79 \mathrm{nGy} / \mathrm{h}$, approximately. In contrast with the world average value of $59 \mathrm{nGy} / \mathrm{h}$ suggested by ${ }^{(22)}$, this current study with the highest value of $79 \mathrm{nGy} / \mathrm{h}$ is higher by a factor of $1.34(\sim 134 \%)$. This shows that site 7 may pose higher radiation risks to the inhabitants when compared to the international reference level ${ }^{(22)}$.

\section{Activity concentrations of U-238, Th-232 and K-40 from Iju River soil}

The seasonal variations of the activity concentrations of U-238, Th-232 and K-40 emitted from the soil sediment samples during dry season (season 3) are presented in Figures 3, 4 and 5, respectively. The activity concentrations of U-238 in Figure 3 shows that the distributions were not uniform. The lowest values of $25.61 \mathrm{~Bq} / \mathrm{kg}$ on the iso-contour map reported at the extreme Eastern part of the study area, whereas the highest value of $\sim 29.94 \mathrm{~Bq} / \mathrm{kg}$ on the Isocontour map reported towards the northern part. The highest distribution of U-238 has a trend of distribution tilting towards the Northwest. The activity level of U-238 in the study area ranges between 19.4 and $32.7 \mathrm{~Bq} / \mathrm{kg}$ approximately. Comparing these values with the earlier study during rainy season monitoring $\mathrm{by}^{(12)}$, with an activity level of $14.5-31.8 \mathrm{~Bq} / \mathrm{kg}$, this current study indicates that they are within the same activity level. Considering the activity level of Th232 distribution on the Iso-contour map presented in Figure 4, it can be observed that the highest value of $103.2 \mathrm{~Bq} / \mathrm{kg}$ reported at the extreme southern part of the study area. The distribution of Th-232 is $\mathrm{N}-\mathrm{S}$ direction with a possible reassemble at station 12 and 13, respectively. The lowest activity level of Th-232 is noted at the upper most part (Northern part) of the study area. The activity concentration of the Th-232 distributed in the study area during dry season varies between 10.9 and $103.2 \mathrm{~Bq} / \mathrm{kg}$. Comparing these activity levels with ${ }^{(12)}$, who reported earlier study conducted during rainy season, it can be observed that the values ranging between $22.6 \pm 0.3$ and $48.0 \pm 1.9 \mathrm{~Bq} / \mathrm{kg}$ have significant variation with the present study. On the other hand, the activity concentrations of K-40 distributed on the Iso-contour map reported the highest value of $802.2 \mathrm{~Bq} / \mathrm{kg}$ at station 13 , whereas the lowest value of $233.3 \mathrm{~Bq} / \mathrm{kg}$ was noted in station 11 , which is in between North and Eastern part of the study area. The K-40 activity concentrations in the study 


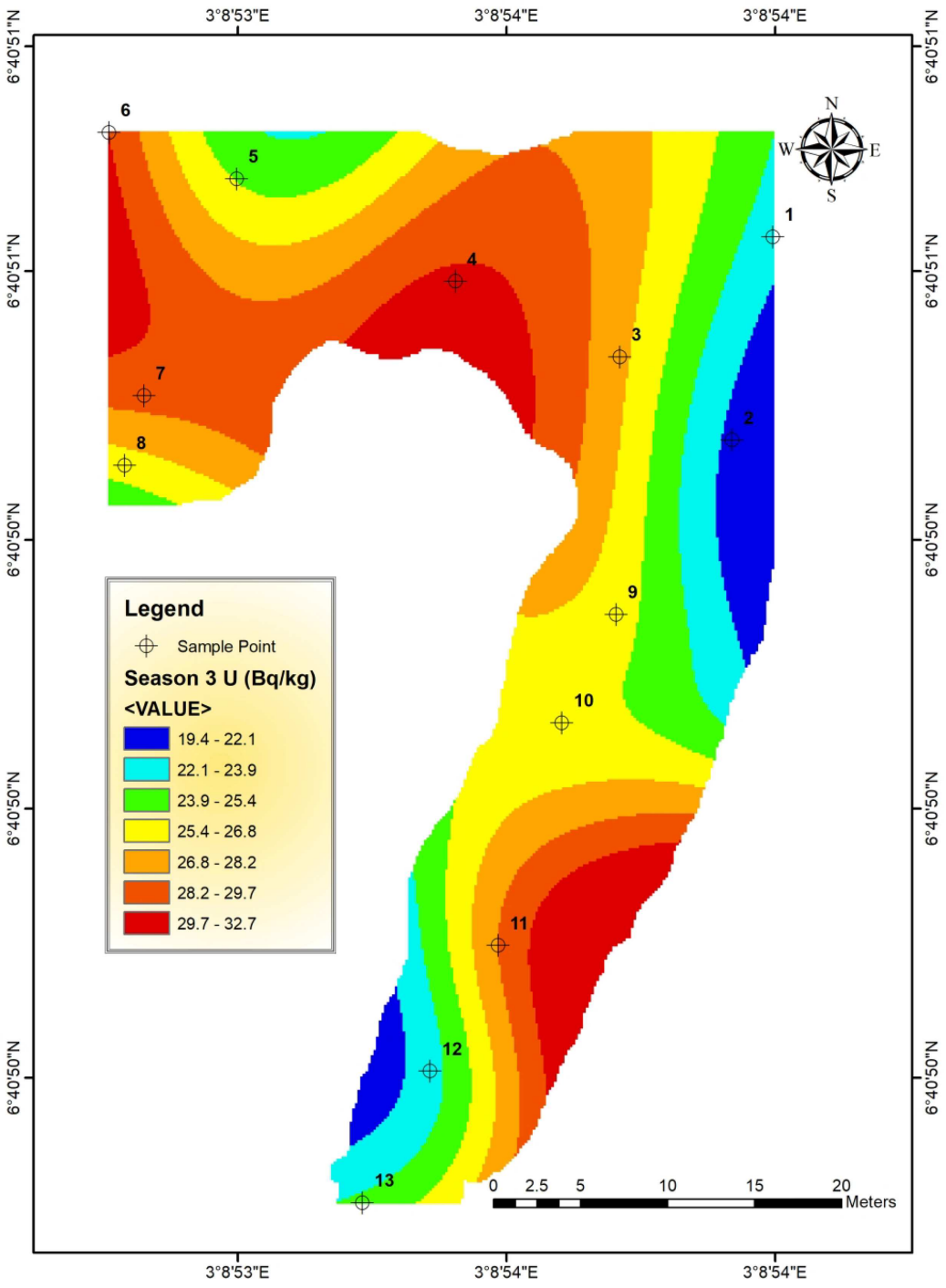

Figure 3: Spatial distribution of U-238 in the study area.

area ranges from 126.5 to $856.9 \mathrm{~Bq} / \mathrm{kg}$. Comparing these ranged values with ${ }^{(12)}$ report conducted during rainy season with a range of values $148.7 \pm 5.3$ to $852.9 \pm 14.7 \mathrm{~Bq} / \mathrm{kg}$, it can be found that the present study is slightly lower, which has significant seasonal variation. The mean values obtained from this study were compared to these international standard values of 33,45 and $420 \mathrm{~Bq} / \mathrm{kg}$ recommended by ${ }^{(21)}$, the values for this current study shows that the values of $32.7 \mathrm{~Bq} / \mathrm{kg}$ is lower by a factor of 0.1 $(\sim 10 \%)$; whereas Th-232 and K-40 are higher by factors of $0.31(\sim 31 \%)$ and $0.22(\sim 22 \%)$, which is also in the range of earlier report by Maxwell et al. ${ }^{(12)}$. Significantly, activity concentration of Th-232, which is far higher than the world average was scooped from the station 2, 12 and 13, presumed to be the channel of the river-laterite contact zone according to Maxwell et $a l .{ }^{(12)}$, is almost the same activity level with the values obtained during this current dry season monitoring.

\section{Radium equivalent ( $\mathrm{R}_{\text {equ }}$ )}

The Radium equivalent $\left(\mathrm{Ra}_{\text {equ }}\right)$ which is a weighted sum of the radioactivity level of Ra-226, Th-232 and $\mathrm{K}-40$ in the sediment sample was calculated. 


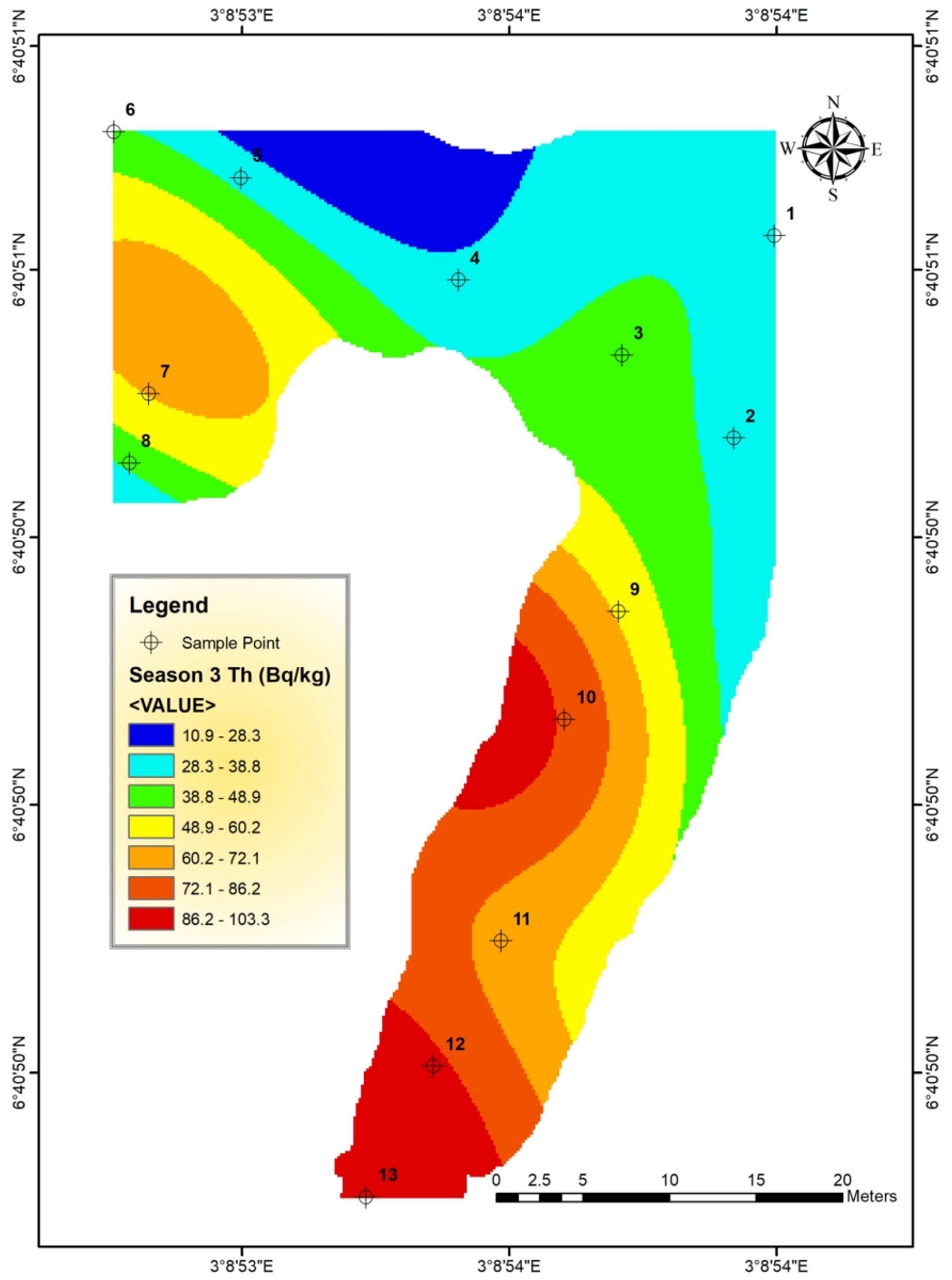

Figure 4: Spatial distribution of Th-232 in the study area.

This allows the comparison with their individual Ra226, Th-232 and K-40 activity concentrations ${ }^{(12,23)}$. This is assumed that all Ra-226 and Th-232 decay products are in radioactive equilibrium with their progeny ${ }^{(12)}$. This Radium equivalent will provide a guideline in regulating the general public safety standard of radioprotection of the people residing in the area. This index is the most widely used to assess the radiation hazard, which is calculated according to Equation $(2)^{(22,24)}$.

$$
R a_{\mathrm{eq}}=C_{U}+1.43 C_{T h}+0.077 C_{K}
$$

where $\mathrm{C}_{\mathrm{U}}, \mathrm{C}_{\mathrm{Th}}$ and $\mathrm{C}_{\mathrm{K}}$ are the specific activities of $\mathrm{U}-238$, Th-232 and $\mathrm{K}-40$ measured in $\mathrm{Bq} / \mathrm{kg}$, respectively. This formula estimates that $1 \mathrm{~Bq} / \mathrm{kg}$ of $\mathrm{U}$ $238,0.7 \mathrm{~Bq} / \mathrm{kg}$ of $\mathrm{Th}-232$ and $13 \mathrm{~Bq} / \mathrm{kg}$ of $\mathrm{K}-40$ that produces the same gamma dose rates. The $\mathrm{Ra}_{\text {equ }}$ is related to both internal doses due to the radon and external gamma dose and should not exceed $370 \mathrm{~Bq} / \mathrm{kg}^{(23)}$. It can be observed from Figure 6 that the $\mathrm{Ra}_{\text {equ }}$ varies between 89.4 and $233.7 \mathrm{~Bq} / \mathrm{kg}$ with the highest value found in in site 13 sample. The lowest value of $89.4 \mathrm{~Bq} / \mathrm{kg} \mathrm{Ra}$ equ activities was noted during the dry season in site 1 . Comparing the mean values of $144 \mathrm{~Bq} / \mathrm{kg}$ for $\mathrm{Ra}_{\text {equ }}$ activity of this present 


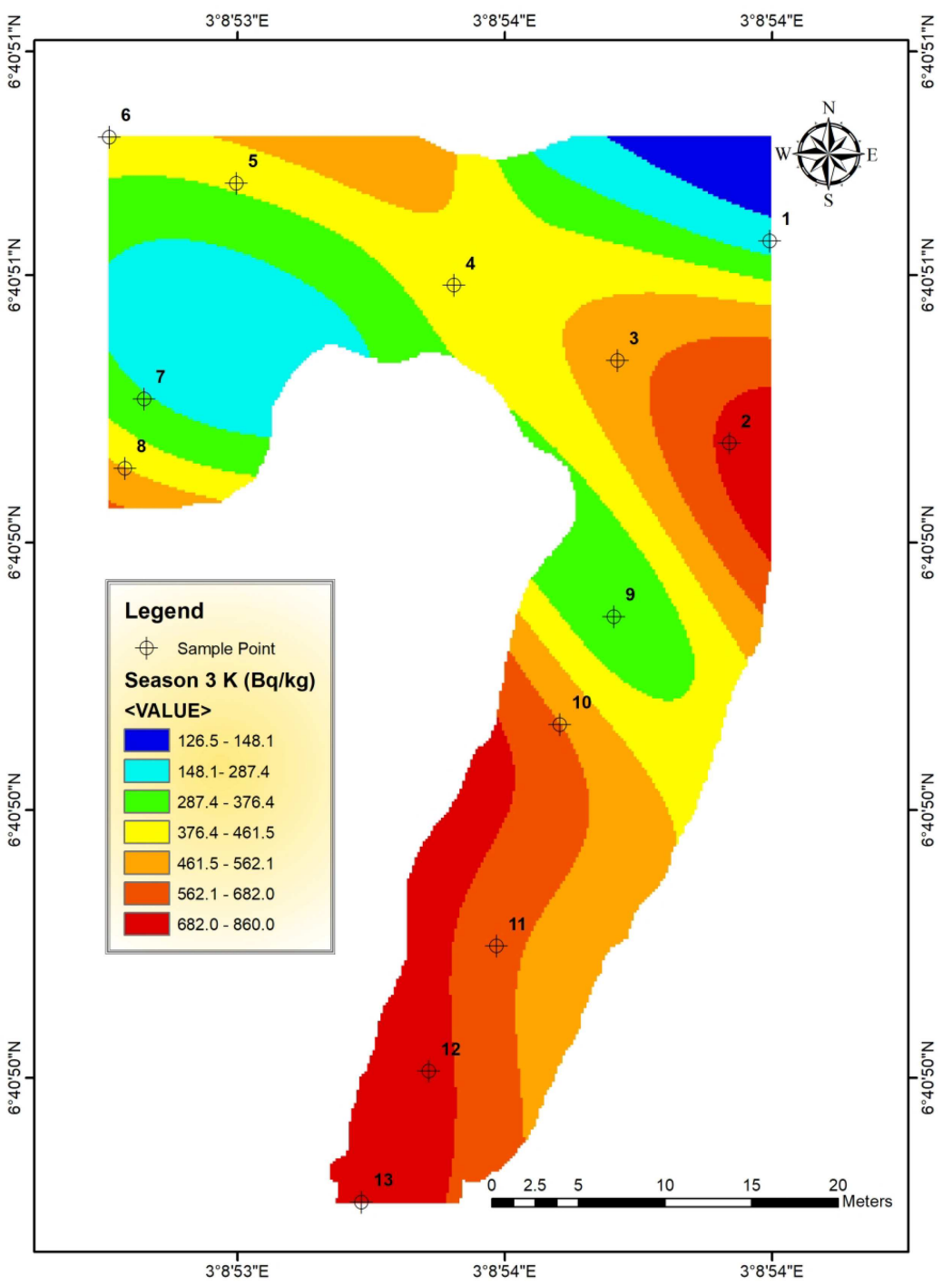

Figure 5: Spatial distribution of K-40 in the study area.

study with the ${ }^{(12)}$, with a value of $113.0 \mathrm{~Bq} / \mathrm{kg}$, this current study is higher, but lower than the international standard value of $370 \mathrm{~Bq} / \mathrm{kg}$ according to (23).

\section{Absorbed Dose Rate (DC) from Riverine Sediments Samples for the Dry Seasons}

The calculation of the dose rate, which is the outdoor absorbed dose rate in $\mathrm{nGy} / \mathrm{h}$ in the air from background gamma radiation at $1 \mathrm{~m}$ above the ground which is calculated by using $\mathrm{nGy} / \mathrm{h}$ per $\mathrm{Bq} / \mathrm{kg}$ conversion factor to transform the specific activities of $\mathrm{C}_{\mathrm{Ra}}$,
$\mathrm{C}_{\mathrm{Th}}$ and $\mathrm{C}_{\mathrm{K}}$ in the sediment samples into absorbed dose rate ${ }^{(12,22,25,26)}$. Equation (3) is used to calculate the absorbed dose rates due to the radionuclides gamma radiation in the air.

$$
\begin{aligned}
D_{c}= & 0.462 C(U-238)+0.604 C(T h-232) \\
& +0.0417 C(K-40)
\end{aligned}
$$

Considering the gamma dose rates presented in Figure 7, the lower gamma dose rate measured in the samples during the dry season was found in site 1 


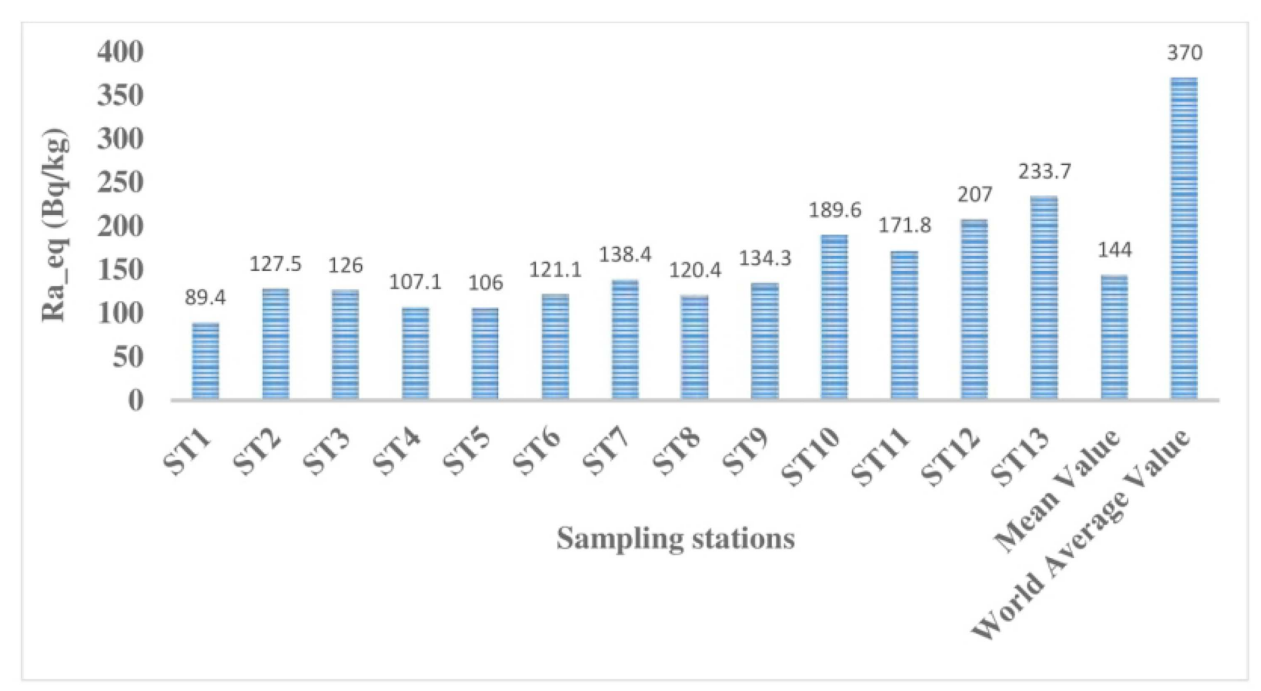

Figure 6: Radium equivalent activity against sampling stations.

Table 1. Analysis of variance of U-238 $(\mathrm{Bq} / \mathrm{kg})$ and Th-232 $(\mathrm{Bq} / \mathrm{kg})$ for the Sediment Samples.

\begin{tabular}{llllll}
\hline Source & DF & Adj SS & Adj MS & F-Value & P-Value \\
\hline Factor & 2 & 1827227 & 913614 & 86.68 & 0.000 \\
Error & 36 & 379445 & 10540 & & \\
Total & 38 & 2206673 & & & \\
\hline
\end{tabular}

with a value of $40.8 \mathrm{nGy} / \mathrm{h}$, while the highest value of $107.0 \mathrm{nGy} / \mathrm{h}$ was noted in site 13 . The determined mean value of the gamma dose obtained from the river sediment samples was $66.5 \mathrm{nGy} / \mathrm{h}$. In contrast with the earlier study of the river sediments monitoring in rainy season by ${ }^{(12)}$ with a value of $68.9 \mathrm{nGy} / \mathrm{h}$, this present study is slightly lower. Comparing this highest value of $66.5 \mathrm{nGy} / \mathrm{h}$ with the world average value of $84 \mathrm{nGy} / \mathrm{h}$, this present study is distinctly lower by a factor of $1.3^{(22)}$.

\section{Multivariate statistical analysis of relationship between $\mathrm{U}-238$, Th-232 and $\mathrm{K}-40$}

Analysis of variance was made for $\mathrm{U}-238(\mathrm{~Bq} / \mathrm{kg})$, Th-232 (Bq/kg), and K-40 (Bq/kg) on Minitab 17 with significance level of $\alpha=0.05$. The ANOVA table (Table 1) shows a relative significant variation between the three factors studied indicated by the $P$ Value (0.000) being less than the significance level of $\alpha=0.05$.

The linear relationship between $\mathrm{K}-40(\mathrm{~Bq} / \mathrm{kg})$ and Th-232 $(\mathrm{Bq} / \mathrm{kg})$ is significant because the positive correlation coefficient is 0.603 and the corresponding $P$-value is 0.029 as shown in Table 2 . As it can be observed, in Figures 8 and 9, respectively, were confirmed to be showing negative correlation and also relatively non-linear relationship between U-238 and $\mathrm{Th}-232$ in the sediment samples from the riverine area of Ado-Odo Ota. On the other hand, Figure 10 shows the most linear trend and this confirms the positive correlation between $\mathrm{K}-40(\mathrm{~Bq} / \mathrm{kg})$ and Th$232(\mathrm{~Bq} / \mathrm{kg})$ in the sediment samples from the riverine area.

\section{Monte Carlo simulation}

Analysis of risk plays a very important role in decision making particularly from an environmental protection point of view. Researchers are continuously faced with obscurities and uncertainties. While overestimation of the health risks (i.e. the absorbed dose rates and Radium equivalent activities) can lead to waste of resources on unnecessary mitigation exercise, underestimation of these risks can give rise to severe health consequences to the inhabitants ${ }^{(27)}$. Estimation of the mean values using the assessment model given by Equations 2 and 3, either overestimates or underestimates the real risk. Thus, probabilistic approach using the MCS has been appositely used in this research 


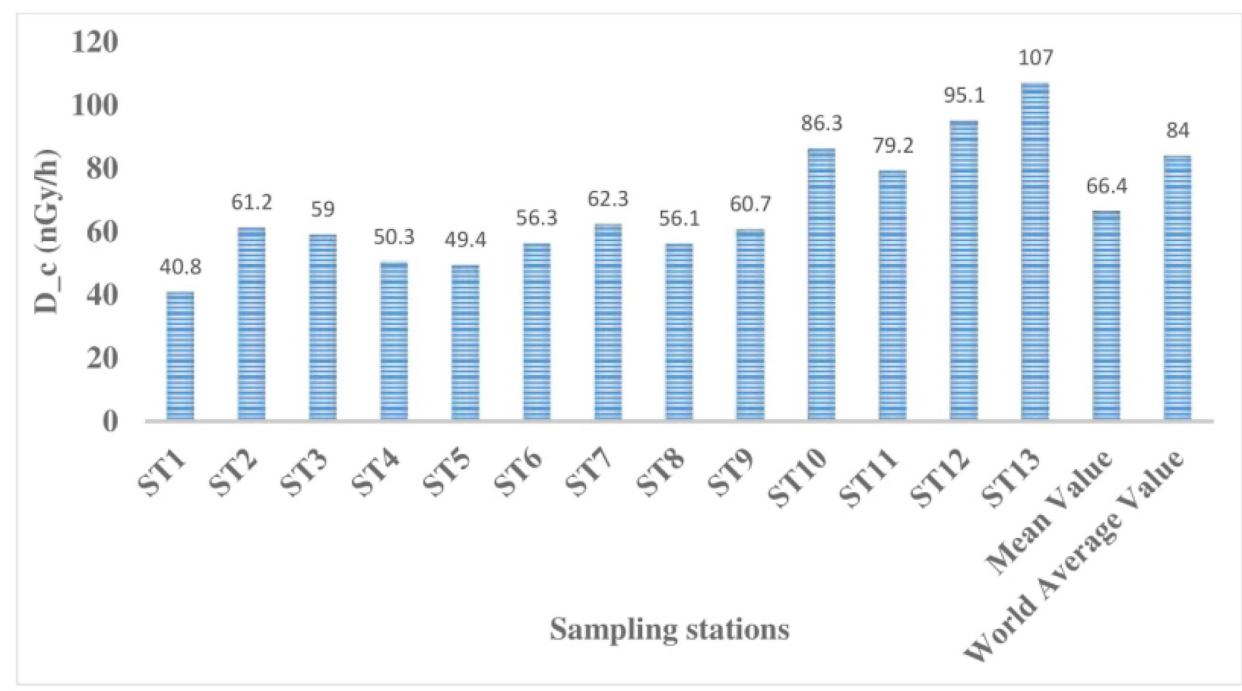

Figure 7: Absorbed dose rates against stations.

Table 2. Correlation between the specific activities of $\mathrm{U}-238(\mathrm{~Bq} / \mathrm{kg}), \mathrm{Th}-232(\mathrm{~Bq} / \mathrm{kg})$ and $\mathrm{K}-40(\mathrm{~Bq} / \mathrm{kg})$ in the sediment samples from the riverine area.

\begin{tabular}{lll}
\hline Correlation & $\mathrm{U}-238(\mathrm{~Bq} / \mathrm{kg})$ & Th-232 $(\mathrm{Bq} / \mathrm{kg})$ \\
\hline Th-232 $(\mathrm{Bq} / \mathrm{kg})$ & -0.185 & \\
& 0.546 & 0.603 \\
$\mathrm{~KB}-40(\mathrm{~Bq} / \mathrm{kg})$ & -0.360 & 0.029 \\
Cell Contents & 0.227 & \\
$P$-Value & Pearson correlation & \\
\hline
\end{tabular}

to assess more realistic risk related to the primordial radionuclides (U-238, Th-232 and K-40) present in the samples. MCS has the advantage of letting researchers see all the possible outcomes for decisions and assess the impact of risk, giving room for better decision making under uncertainty. It executes the risk analysis through building models of probable results by exchanging array of values (probability distribution) for any factor with intrinsic uncertainty ${ }^{(27)}$. The MCS then computes the results multiple times (10 000 trials were adopted in this work), in each occasion expending different arbitrary values from the probability functions. Probability distributions are a much more realistic way of describing uncertainty in variables of a risk analysis. The software used in this work to perform the MCSs is Oracle Crystal Ball software version 11.1.2.4.850.

The result of the MCS is provided in Table 3 and Figures 11 and 12, respectively. The mean, 5th and 95th percentiles of the probabilities for the Radium equivalent activity are 146.00, 91.10 and 203.00 Bq/kg, respectively. The mean, 5th and 95th percentiles of the probabilities for the absorbed dose rate are found to be 67.30, 42.90 and 92.20, respectively. Both the estimated values for the Radium equivalent activities and the absorbed dose rates are less than their respective limits of $370 \mathrm{~Bq} / \mathrm{kg}$ and $84 \mathrm{nGy} / \mathrm{h}$ recommended in literature ${ }^{(23,26)}$.

\section{CONCLUSION}

The terrestrial gamma dose rates in the study area revealed the hotspot in station 7 , which could be the vulnerable zone to both human and ecosystem in the area since the value obtained there is $134 \%$ higher than the recommended value. The gamma dose measurement indicates higher gamma dose rate of $79 \mathrm{nGy} / \mathrm{h}, \sim 134 \%$ higher than the world average of $79 \mathrm{nGy} / \mathrm{h}$. The values for U-238, Th-232 and K-40 activity levels ranges between 29.9 and $21.6 ; 103.2$ and 31.2; and 802.2 and 233.5 with mean values of 26.1 , 55.6 and $499.3 \mathrm{~Bq} / \mathrm{kg}$, respectively. Comparing the mean values with the earlier study carried out along 


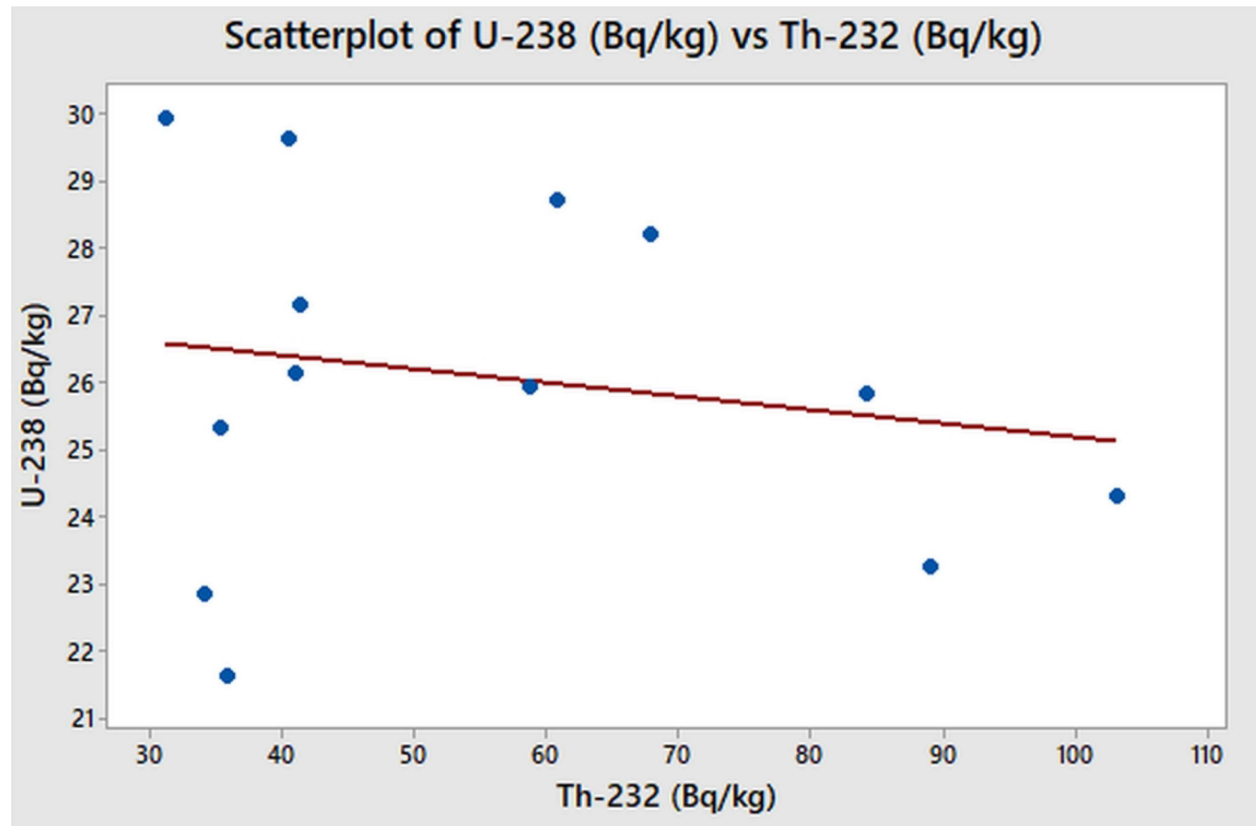

Figure 8: Correlation between the specific activities of U-238 and Th-232 (Bq/kg).

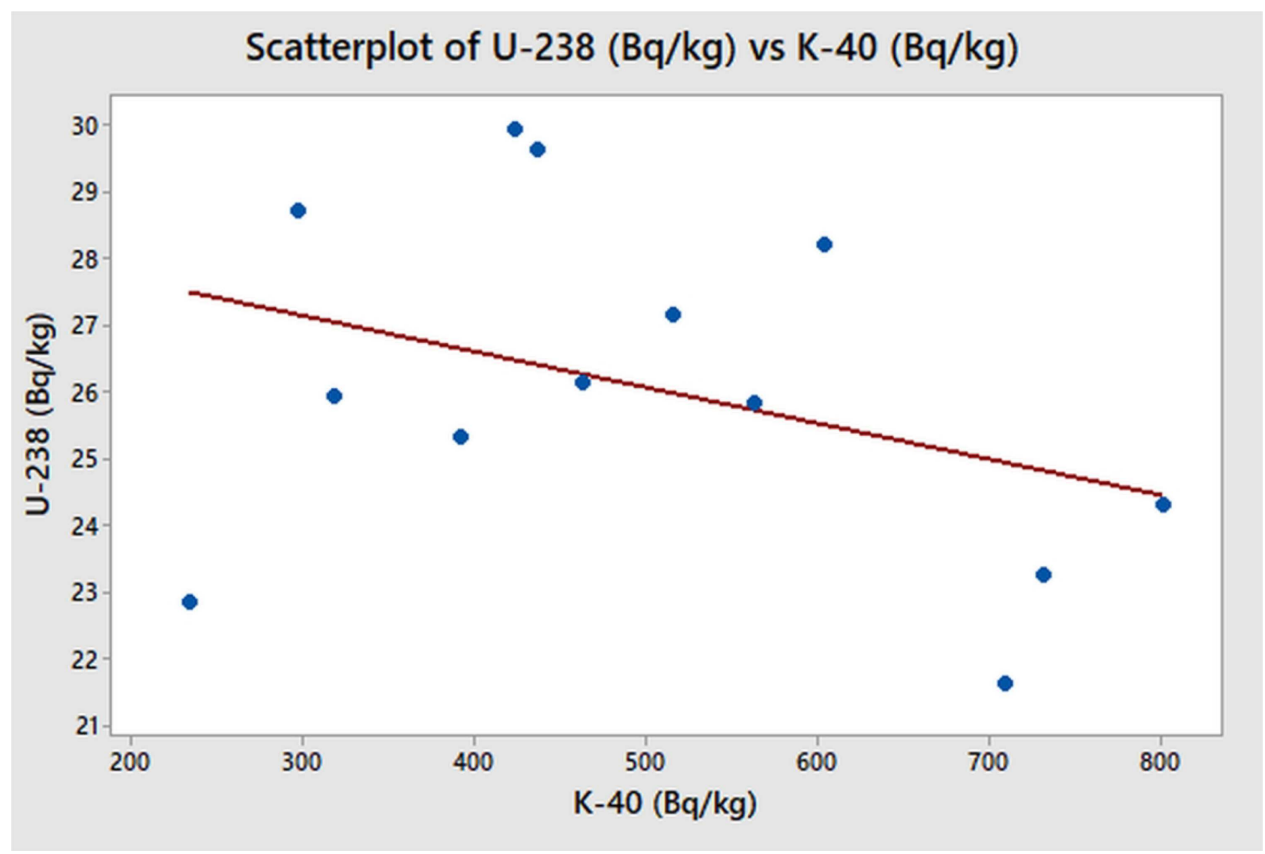

Figure 9: Correlation between the specific activities of U-238 and $\mathrm{K}-40(\mathrm{~Bq} / \mathrm{kg})$. 


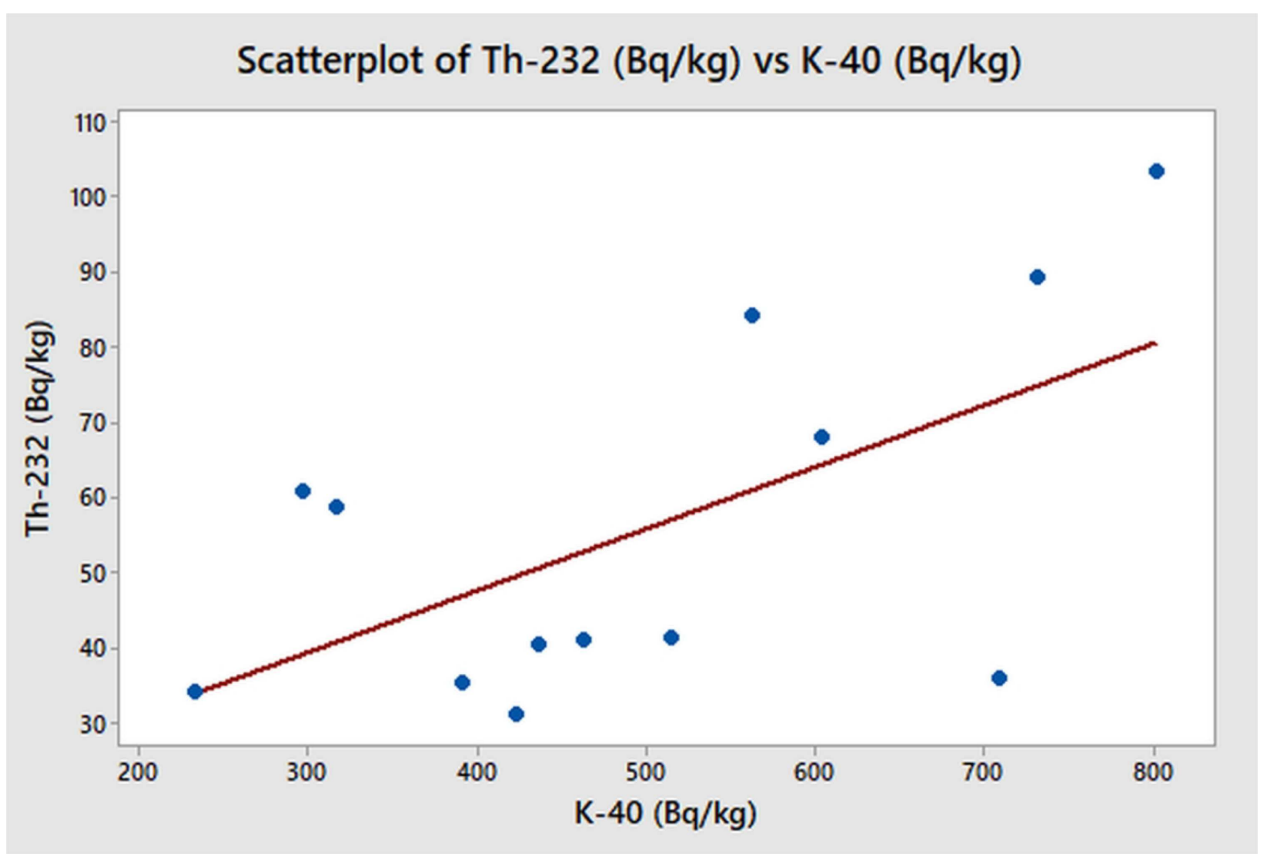

Figure 10: Correlation between the specific activities of Th-232 and K-40 (Bq/kg).

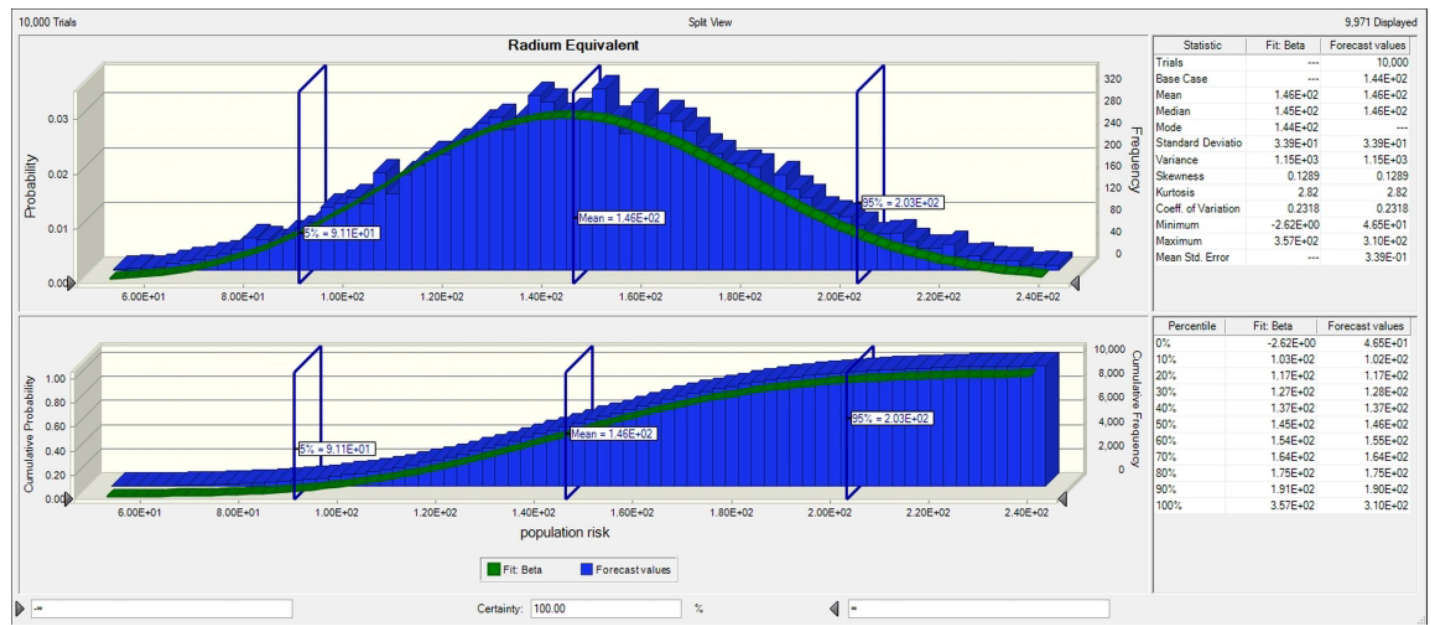

Figure 11: Probability distribution and cumulative probability plots of the radium equivalent.

Table 3. Summary of the MCS.

\begin{tabular}{llll}
\hline & $5 \%$ & Mean & $95 \%$ \\
\hline $\operatorname{Ra}_{\mathrm{eq}}(\mathrm{Bq} / \mathrm{kg})$ & 91.10 & 146.00 & 203.00 \\
$\mathrm{D}(\mathrm{nGy} / \mathrm{h})$ & 42.90 & 673.00 & 92.20 \\
\hline
\end{tabular}


MEASUREMENTS OF SEASONAL VARIATIONS OF RADIOACTIVITY DISTRIBUTIONS

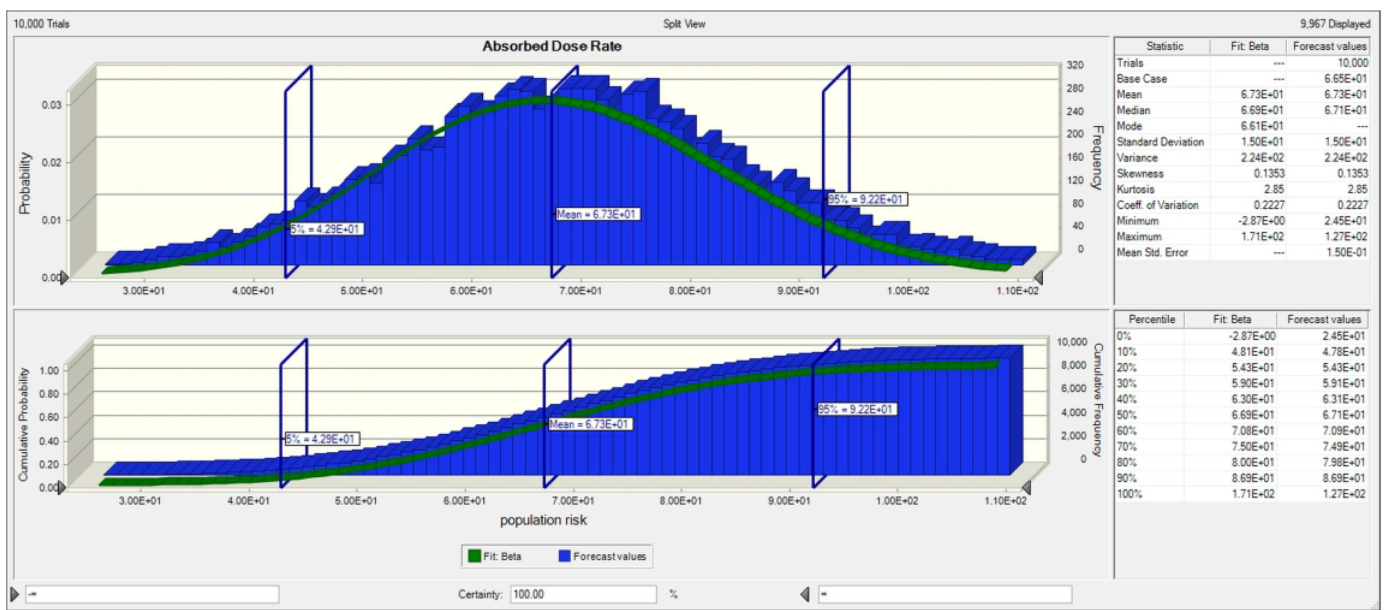

Figure 12: Probability distribution and cumulative probability plots of the absorbed dose rate.

the river sediments during rainy season, with range of activity levels of $14.5-31.8,10.9-103.2$ and $148.7-$ $852.9 \mathrm{~Bq} / \mathrm{kg}$, respectively, for $\mathrm{U}-238$, Th-232 and K40 , it can be observed that they are within the range with slight variations. Statistically, this study confirmed insignificantly negative correlation and also relatively non-linear relationship between U-238 and Th-232 in the sediment samples from the riverine area, whereas a most liner trend and positive correlation between K-40 and Th-232 were confirmed. The risk analysis according to the mean, 5th and 95th percentiles of the probabilities due the activities of these radionuclides using the MCS reveals that the estimated values for the Radium equivalent activities and the absorbed dose rates are less than their respective limits of $370 \mathrm{~Bq} / \mathrm{kg}$ and $84 \mathrm{nGy} / \mathrm{h}$, respectively, recommended by UNSCEAR.

This study could be used to monitor other riverine areas in West African Region as baseline data.

\section{ACKNOWLEDGEMENT}

The authors would like to thank Covenant University for creating the enabling Environment for the execution of this research.

\section{CONFLICT OF INTEREST}

All the authors do not have any conflict of interest or financial interest that could jeopardize this present article.

\section{REFERENCES}

1. Uluturhan, E., Kontas, A. and Can, E. Sediment concentrations of heavy metals in the Homa Lagoon (Eastern Aegean Sea): assessment of contamination and ecological risks. Mar. Pollut. Bull. 62, 1989-1997 (2011).
2. Szefer, P., Glasby, G. P., Stuben, D., Kusak, A., Geldon, J., Berner, Z., Neumann, T. and Warzocha, J. Distribution of selected heavy metals and rare earth elements in surficial sediments from the Polish sector of the Vistula Lagoon. Chemosphere 39, 2785-2798 (1999).

3. Sylaios, G., Kamidis, N. and Stamatis, N. Assessment of trace metals contamination in the suspended matter and sediments of a semi-enclosed Mediterranean Gulf. Soil Sediment. Contam.: Int. J. 21, 673-700 (2012).

4. Nyarko, E., Botwe, B., Ansong, J., Delfanti, R., Barsanti, M., Schirone, A. et al. Determination of ${ }^{210} \mathrm{~Pb}$, ${ }^{226} \mathrm{R} a$ and ${ }^{137} \mathrm{Cs}$ in beach sands along the coastline of Ghana. Afr. J. Environ. Pollut. Health 9, 17-23 (2011).

5. Isinkaye, M. O. and Emelue, H. U. Natural radioactivity measurements and evaluation of radiological hazards in sediment of Oguta Lake, south East Nigeria. J. Radiat. Res. Appl. Sci. 8, 459-469 (2015).

6. al-Trabulsy, H. A., Khater, A. and Habbani, F. Radioactivity levels and radiological hazard indices at the Saudi coastline of the Gulf of Aqaba. Radiati Phys Chem. 80(3), 343-348 (2011).

7. Jibiri, N. N. and Okeyode, I. C. Evaluation of radiological hazards in the sediments of Ogun River, SouthWestern Nigeria. Radiat. Phys. Chem. 81, 103-112 (2012).

8. Sirelkhatim, D., Sam, A. and Hassona, R. Distribution of 226Rae 210Pbe 210Po in marine biota and surface sediments of the Red Sea, Sudan. J. Environ. Radioact. 99(12), 1825-1828 (2008).

9. Abbasi, A. ${ }^{210} \mathrm{~Pb}$ and ${ }^{137} \mathrm{Cs}$ based techniques for the estimation of sediment chronologies and sediment rates in the Anzali Lagoon, Caspian Sea. J. Radioanal. Nucl. Chem. 322, 319-330 (2019).

10. Emenike, P. C., Neris, J. B., Tenebe, I. T., Nnaji, C. C. and Jarvis, P. Estimation of some trace metal pollutants in River Atuwara southwestern Nigeria and spatio-temporal human health risks assessment. Chemosphere 239, 124770 (2020). doi: 10.1016/j.chemosphere.2019.124770.

11. Singh, P. K. and Saxena, S. Towards developing a river health index. Ecol. Indic. 85, 999-1011 (2018). doi: 10.1016/j.ecolind.2017.11.059. 


\section{O. MAXWELL ET AL.}

12. Maxwell, O., Olusegun O., A., Emmanuel S., J., Ijeh B., I., Uchechukwu A., O., Oluwasegun, A., Ogunrinola E., I., Angbiandoo M., T. T., Ifeany A., O. and Saeed, M. A. Spatial distribution of gamma radiation dose rates from natural radionuclides and its radiological hazards in sediments along river Iju, Ogun state Nigeria. Methods X. 7, 101086 (2020). doi: 10.1016/j.mex.2020. 101086.

13. Olabode, S. O. Siliciclastic slope deposits from the Cretaceous Abeokuta Group, Dahomey (Benin) Basin, southwestern Nigeria. J. African Earth Sci. 46, 187-200 (2006)

14. Omatsola, M. E. and Adegoke, O. S. Tectonic evolution and cretaceous stratigraphy of the Dahomey basin. Nigeria Geol. 18(51), 130-137 (1981).

15. Mutiu, A. A., Gbolahan, I., Oluwaseyi, A. O., Folashade, H. F., Adeyemi, Y. A., Taofeeq, A. A. and Adelowo, A. A. Water Quality Assessment of Iju River in Ogun State, Nigeria: effect of human activities. J. Environ. Sci. Toxicol. Food Technol. 6(3), 64-68 (2013).

16. Radiation Solution Inc. RS-125/230 User Manual, Revision 1.05-December 2015, Firmwave Version 5v95, Part Number D-1009(2015). In: . p. 7 (2015).

17. Mama, C. N., Nnaji, C. C., Emenike, P. C. and Chibueze, C. V. Potential environmental and human health risk of soil and roadside dust in a rapidly growing urban settlement. Int. J. Environ. Sci. Technol. (2020). doi: 10.1007/s13762-020-02637-9.

18. Omeje, M., Wagiran, H., Ibrahim, N., Lee, S. K. and Soheil, S. Comparison of ${ }^{238} U,{ }^{232} \mathrm{Th}$, and ${ }^{40} \mathrm{~K}$ in different layers of subsurface structures in Dei-Dei and Kubwa. Abuja. Radi. Phy. Chem. 91, 70-80 (2013).

19. Orosun, M. M., Usikalu, M. R., Oyewumi, K. J. and Achuka, J. A. Radioactivity levels and transfer factor for granite mining field in Asa, Northcentral Nigeria. Heliyon. 6(6), e04240 (2020). doi: 10.1016/j.heliyon.2020.e04240.

20. Ravisankar, R., Vanasundari, K., Suganya, M., Raghu, Y., Rajalakshmi, A., Chandrasekaran, A., Sivakumar, S., Chandramohan, J., Vijayagopal, P. and Venkatra- man, B. Multivariate statistical analysis of radiological data of building materials used in Tiruvan-namalai, Tamilnadu. India. Appl. Radiat. Isot. 85, 114-127 (2014).

21. Ravisankar, R., Sivakumar, S., Chandrasekaran, A., Prince Prakash Jebakumar, J., Vijayalakshmi, I., Vijayagopal, P. and Venkatraman, B. Spatial distribution of gamma radioactivity levels and radiological hazard indices in the East Coastal sediments of Tamilnadu, India with statistical approach. Radiati Phys Chem. 103, 89-98 (2014). doi: https://doi.org/ 10.1016/j.radphyschem.2014.05.037.

22. Abbasi, A. and Mirekhtiary, F. Heavy metals and natural radioactivity concentration in sediments of the Mediterranean Sea coast. Mar. Pollut. Bull. 154, 111041 (2020). doi: https://doi.org/10.1016/j.marpolbul.2020. 111041.

23. UNSCEAR. United Nations Scientific Committee on the Effect of Atomic Radiation: Effects, and Risks of Ionizing Radiation. In: Report to the General Assembly, with Scientific Annexes, 2000. (New York: UN) (2000)

24. Sugandhi, S., Joshi, V. M. and Ravi, P. Studies on natural and anthropogenic radionuclides in sediment and biota of Mumbai Harbour Bay. J. Radioanal. Nucl. Chem. 300(1), 67-70 (2014).

25. Joel, E. S., Maxwell, O., Adewoyin, O., Ehi-Eromosele, C. O. and Saeed, M. A. Comparative analysis of natural radioactivity content in tiles made in Nigeria and imported tiles from China. Sci. Rep. 8, 1842 (2018).

26. Orosun, M. M., Usikalu, M. R. and Oyewumi, K. J. Radiological hazards assessment of laterite mining field in Ilorin, North-central Nigeria. Int. J. Radiat. Res. 18(4), 895-906 (2020).

27. Orosun, M. M., Adewuyi, A. D., Salawu, N. B., Isinkaye, M. O., Orosun, O. R. and Oniku, A. S. Monte Carlo approach to risks assessment of heavy metals at automobile spare part and recycling market in Ilorin. Nigeria. Sci Rep. 10, 22084 (2020). doi: 10.1038/s41598-020-79141-0. 